\title{
Corrigendum: Stormwater Ponds in the Southeastern U.S. Coastal Plain: Hydrogeology, Contaminant Fate, and the Need for a Social-Ecological Framework
}

\author{
Barbara Beckingham *, Timothy Callahan and Vijay Vulava \\ Department of Geology and Environmental Geosciences, College of Charleston, Charleston, SC, United States
}

Keywords: stormwater, pond, green infrastructure, urban development, coastal plain, best management practice

\section{A Corrigendum on}

Stormwater Ponds in the Southeastern U.S. Coastal Plain: Hydrogeology, Contaminant Fate, and the Need for a Social-Ecological Framework

by Beckingham, B., Callahan, T., and Vulava, V. (2019). Front. Environ. Sci. 7:117. doi:10.3389/fenvs. 2019.00117

In the original article, we mistakenly stated that "there are over 14,000 stormwater ponds in the 20 coastal counties of North Carolina (Gona, 2016)". This figure, more exactly 15,527, actually describes the number of post-construction stormwater permitted regulated activities in the 20 coastal counties of NC. An inventory of stormwater pond number in coastal North Carolina is currently unavailable. According to NC Department of Environmental Quality records (personal communication, February 2021), of the total permitted activities, there are 4,451 high-density sites that require a stormwater control measure. Of these, 2,729 use detention ponds but there may be more than 1 pond per site. Detention ponds are present on these permits more frequently than other stormwater control measures, including infiltration basins, bioretention, sand filters, or constructed wetlands, etc. A correction has been made to the Introduction, paragraph four and the original article has been updated:

"In the coastal plain regions, which are characterized by relatively shallow water tables and low

This article was submitted to Water and Wastewater Management

a section of the journal

Frontiers in Environmental Science

Received: 04 May 2021 Accepted: 07 May 2021 Published: 26 May 2021

Citation:

Beckingham B, Callahan T and Vulava V (2021) Corrigendum: Stormwater Ponds in the Southeastern

U.S. Coastal Plain: Hydrogeology, Contaminant Fate, and the Need for a Social-Ecological Framework.

Front. Environ. Sci. 9:705113. doi: 10.3389/fenvs.2021.705113 hydraulic gradients, stormwater ponds with a permanent pool, typically referred to as wet detention ponds, dominate and are widely visible landscape features. For example, demonstrating the proliferation of stormwater ponds during development, an estimated 10,000 wet detention ponds have been surveyed in urban areas in southwest Florida, most being constructed since 1980 (Thomas and Lucius, 2016). In the 20 coastal counties of North Carolina, stormwater ponds are the most commonly selected stormwater control measure on post-construction stormwater permits, although the number of ponds is yet unknown (Gona, 2016; NC DEQ personal communication, 2021). In a study of 511 ponds in SC, wet detention was the most frequently used type (Drescher et al., 2007). Further, analysis of aerial imagery-based inventories of wet detention ponds has found about 100 ponds were created per year on average in both the Myrtle Beach and Charleston metropolitan areas of SC between 1994 and 2013, with annual rates of change in pond area roughly tracking the rate of change of total developed land area (Smith et al., 2018). Ponds are often a highlighted feature of residential developments that have been designed over the past few decades (Figure 2)." 
It can additionally be noted that two studies cited in the Introduction, paragraph five, Van Metere et al. (2000) and Thapalia et al. (2010), studied urban reservoirs and natural ponds or lakes that are larger than typical stormwater ponds. The fact that stormwater ponds "either trap or act as a gateway for the transport of various environmental pollutants to receiving bodies" is supported by additional studies referenced, including Gold et al. (2017b), Hathaway et al. (2009), and Koch et al. (2014), as well as a more recent study not included in original review by McCabe et al. (2021) (Environ. Sci. Technol. 55:952-961, doi: 10.1021/acs.est.0c04502).

\section{REFERENCE}

McCabe, K. M., Smith, E. M., Lang, S. Q., Osburn, C. L., and Benitez-Nelson, C. R. (2021). Particulate and Dissolved Organic Matter in Stormwater Runoff Influences Oxygen Demand in Urbanized Headwater Catchments. Environ. Sci. Technol. 55, 952-961. doi:10.1021/acs.est. 0c04502
We apologize for the need for correction and state that this does not change the scientific conclusions of the article in any way.

\section{AUTHOR CONTRIBUTIONS}

$\mathrm{BB}$ wrote the corrigendum and it was approved by all authors for publication.

Conflict of Interest: The authors declare that the research was conducted in the absence of any commercial or financial relationships that could be construed as a potential conflict of interest.

Copyright (c) 2021 Beckingham, Callahan and Vulava. This is an open-access article distributed under the terms of the Creative Commons Attribution License (CC BY). The use, distribution or reproduction in other forums is permitted, provided the original author(s) and the copyright owner(s) are credited and that the original publication in this journal is cited, in accordance with accepted academic practice. No use, distribution or reproduction is permitted which does not comply with these terms. 